\title{
Mass Communication and Sustainable Political Development in Africa: A Review of the Literature
}

\author{
Ephraim Okoro \\ Department of Marketing, School of Business, Howard University, USA \\ Correspondence: 2600 Sixth Street, NW, Washington, D.C., USA. E-mail: eaokoro@ howard.edu
}

Received: December 30, 2012 Accepted: January 11, 2013 Available online: February 20, 2013

doi:10.11114/smc.v1i1.71

URL: http://dx.doi.org/10.11114/smc.v1i1.71

\begin{abstract}
With the globalization of economies over the past two decades, there has been an increasing surge in Africa for strategic political and economic relationships. Unfortunately, the political systems in the continent present serious challenges to the rest of the world as they view the countries in Africa as politically unstable and economically unsustainable. In recent years, Africa's political process, especially the electoral system, has been discredited as incapable of supporting a viable democracy and political governance. Current trends in Africa's political development efforts in the twenty-first century clearly indicate that to achieve and sustain democratic transformation in the entire continent, the role of the mass media, especially the new media, is critical in the production and dissemination of news and political reforms. This paper provides a comprehensive analysis of the role of mass communication in the political development in contemporary Africa. It specifically examines the relationship between political systems and the media in Africa, probes the strategic role of new media in the quest for sustainability of the political process, and discusses media's contributions in encouraging citizens' participation in political governance. The paper concludes with recommendations for integrating the role of the mass media in achieving political development and stability in the continent of Africa.
\end{abstract}

Keywords: mass media, political development, globalization, sustainable political systems, political governance, democratic transformation

\section{Introduction}

A number of mass media scholars (Bennett, 2003; Diamond, 2004; Graber, 2010) have noted that democratization and the processes of achieving it must be tailored toward increasing domestic and global awareness and developing sophisticated citizenry. More than ever before, African governments have consistently indicated their commitment to political and economic development, but this laudable objective seems far-fetched as a result of the minimal role of the media in educating the public and encouraging effective participation and responsiveness. Indeed, as the debate on Africa's development agenda and reforms continues to take different and complex dimensions, scholars across development and political disciplines (Ziegler \& Asante, 1992; Okoro, 1993; M’Bayo, Nwokeafor, \& Onwumechili, 1995; Entman, 1989) strongly suggest that the new media system should be effectively utilized as agents for sustainable political landscape in the countries of Africa.

Over several decades, the sensitive issue of the relationship between African media and government establishments has been viewed as instrumental to the growing instability and apathy among the citizens. Recent studies by African scholars (Guta, 2010; Langmia, 2010; Okoro, 2010) examined the role of the media in the development process and identified the variables that could contribute to sustainable development. Because of decades of perpetual conflict between the media and politics about the functions of the former, various political climates in African countries were analyzed for context, background, and relationships.

Indeed, the central focus of this paper is the nature of media-government relationship in the quest for sustainable political development; and concomitantly, the extent to which the relationship is hindering or enhancing the effectiveness of the media in mobilizing citizen's support for political awareness and development. As Gyimah-Boadi (2004) noted, the surge in despair over African political and economic prospects at the turn of the twenty-first century raised alarming concerns about the structure of political reforms, democratization, and developments. For various reasons, the continent of Africa has attracted the most dramatic political changes over 
the past decades. Some of the countries were victims of decades of military and corrupt civilian rules, culminating in a range of financial and economic abuses which the media could not expose, discuss, or disseminate.

Based on recent analysis of both African and international scholars, the entire African continent has lagged behind in terms of political and economic development because of shortsighted and selfish governance. Political leaders were both self-serving and unaccountable to the people, and the political system lacked transparency and integrity. The mass media faced the challenge of inability to provide objective information to the public for decision-making. While numerous indigenous newspapers sprang up to challenge the political and economic abuses by the governments, they were grossly unable to make any meaningful impact in terms of increasing public interest and participation. Historical evidence and empirical analyses (Okoro, 1993; Okigbo, 1992; Mukasa, 2000) consistently indicate that state/government ownership of communication channels became a more rampant phenomenon after independence of many African nations, resulting in charges of political and ethnic/tribal intimidation, news suppression, and personal/leadership aggrandizement. It was noted that successful mobilization of capital, manpower, and hardware by a group of African elites led to the emergence of national newspapers designed to expand and encourage active public involvement and broad participation in politics. While the publications of some of the newspapers were short-lived because of bankruptcy and government prohibitions, their editorial quality and contributions facilitated the struggle for political awareness through the creation of African consciousness and mobilization of citizens' support for nation-building.

For much of the African continent, media ownership and news dissemination were operated under two broad categories - government and private - but the quality of information did not encourage effective citizens' participation in the political process. The coverage of political news and economic development was driven by ethnic or tribal interests, which led to imbalance in overall national development. For example, government media usually provided information related to government activities and programs, while private channels covered news from the perspective of their proprietors and emphasizing issues of ethnic specific interests and sentiments. For decades, it was contended (Uche, 1991; Ziegler \& Asante, 1992) that the mass media in Africa were grossly unable to play the type of role necessary to advance the political interests of African nations. Indeed, the most obvious trend in African journalism, apart from the proliferation of newspapers and other news-sources, is the increasing incidence of state control and the suppression of competing news sources.

\section{Sustainable Political Development}

Both political scientists and communication scholars have grappled with discussions of development and sustainability. For many centuries, the overriding ambition of many societies is to improve the quality of life over time and to transform conditions that contribute to achieving higher and better standards of living. For example, the common objective, vision, and shared commitment of a number of African leaders have been to eliminate poverty, corruption, and establish better living conditions for their citizens. Other critical variables in their view of political development include ethical and credible governance, respect for human rights, ethnic integration, equal tribal participation in the democratic process, stability and security in African nations, resolution and prevention of ethnic/tribal and national conflicts, and gender equality in the political process and public administration. Evidently, the challenge that faces the entire continent of Africa is no longer the articulation of development or the variables associated with political or economic development; rather, establishing a sustainable development framework that can support a viable democratic agenda over a sustained period of time.

In the decades of the 70 s through the 90 s, there was an array of academic research, independent studies, and scholarly debates of national, political, and economic development in Africa. Among them, Opubor (1974) operationalized development as involving the creation of opportunities for the realization of human potentials. Rodney (1974) summarized it as increased skill and capacity, greater freedom, creativity, self-discipline, and material well-being of an individual. Beltran (1974) rationalized development as a participatory process in the economic and political processes leading to technological and ecological transformation of a nation. Awa (1989) synthesized development as a process that should meet, improve, and transform basic human and societal needs. In consonance with others, Uche (1991) identified development with consistent economic and national improvement of a country over period of time.

Furthermore, The World Bank (2006), Graber (1990), and Casmir (1989) determined that development should ultimately lead to political sophistication that ensures stability and economic growth. This study examines political development from the analytical context of author Wilmot (1981, p. 3) as "the action of men attempting to bring political meaning and order into an institution where power is being exercised." According to the report 
of The World Bank (1989) entitled "Sub-Saharan Africa from Crisis to Sustainable Growth," African nations have long seen greater regional integration and cooperation as prerequisites for sustainable political growth and development, but that the objective of political reform and democratization may not be easily realized if the mass media are unable to disseminate knowledge and information freely and independently.

Ever since it became a political issue in the wake of the struggle for democratization among the developing nations of Africa, the concept of development has been conceptualized to reflect national growth, democratic sustainability, or political stability. However, an extensive review of the literature provides a new conceptualization of development driven toward the utilization of communication channels as agents of political development and national growth. Recent media research studies have focused specifically on the application of development communication to sustain democracy and political reforms. In fact, looking back over the past decades of communication research on development, it can be argued that the potential role of the mass media in supporting development is much greater nowadays than ever before, at least in measuring their contributions to democratic sustenance, public awareness, and increased citizens' interest in political participation in developing nations of Africa. A civil society and the mass media are needed to establish and maintain a political environment in which all forms of corruption, fraud, embezzlement, and financial dishonesty can be avoided or reduced to its barest minimum. Through the intervention and exposure by the news media, unethical behaviors in public institutions can be detected and discontinued. A sustainable political development in Africa is attainable and should be cultivated with an integration of the mass media as effective agents of social and political change.

\section{Communicating Sustainable Development in Africa}

Evidently, in the media dominated and controlled environment of the $21^{\text {st }}$ century, radio, newspapers, television, and the internet are playing an increasing role in political development by constantly informing and validating the views of the citizens, and by providing the information needed to shape their political thoughts and evaluations. Political trends in developing worlds would be difficult without the media moving or disseminating information speedily around urban and rural communities, interpreting and analyzing issues affecting all stakeholders, informing the citizens about the outcomes of current debates, and influencing their decisions with appropriate data sources. Diamond (2004) holds the position that political development occurs in an environment in which the citizens are well educated with political news, activities, and processes, and in which they are allowed and encouraged to participate equally and to play critical roles. In addition, the concept of inclusivity in the political process is central to a sustainable political development. Exclusion of some members of a society or marginalizing their communities does not contribute to political development. Importantly, economic, environmental, social, and cultural issues are critical matters that require appropriate public engagement and governmental intervention for political stability to exist. Independent of each other, Entman (2004) and Faringer (1991) emphasized that the media are significant players in the exchange of information among stakeholders, especially between governments and citizens, and the analysis or information provided by the media is often the only basis upon which citizens can make their decisions and choices on past and present issues. Therefore, the primary role of the media in Africa and in other developing nations, as empirical studies have supported over time, should be to adequately and objectively inform the citizenry.

\section{Media's Role in Democratic Sustainability: Curbing Unethical Practices in Government}

For decades, The World Bank Institute has been instrumental in helping developing countries implement anti-corruption programs in order to support their efforts toward sustaining the growth of their economies and political systems. To achieve this objective, the Governance and Finance Division (WBIGF) has sponsored investigative journalism and mass media workshops in Africa, Central and Eastern Europe, Latin America, and South Asia. It was estimated that more than twenty-five workshops were conducted which involved nearly one thousand news sources (journalists and mass media agents) from several countries. These workshops were designed to encourage the effectiveness of the media in uncovering illegal and unethical activities as well as other forms of corruption in public and private sectors (The World Bank, 2009). Importantly, the effectiveness of the media largely depends on access to information and freedom of expression and dissemination. Therefore, it requires the presence of professional and ethical cadre of investigative news sources who would evaluate and publish information objectively without fear of intimidation or harassment. Other critical issues raised by The World Bank (2009) in determining the relevance of the mass media is the distinction between private and public ownership of the media system, and the need for improved protection and security of media staff (reporters and journalists) in their bid to investigate and expose corrupt practices and activities in countries. Historically, the root of corruption and unethical practices are grounded in the social and cultural history, political, and economic inheritance of many developing nations. Consequently, the presence of investigative media structure is critical to 
sustain political governance. Based on the recommendations of The World Bank (2009) and communications researchers, the role of the media is essential in promoting good governance and discouraging, controlling, and curbing corruption in a political system. The role of an independent media does not only raise public awareness about corruption and unethical behaviors, it also exposes their causes, consequences, and impact on democratic and political process in a country.

Political debates in African countries have taken on new dimension over the past few years in view of the fact that citizens are demonstrating a growing interest in governance and have started holding political leaders accountable for their actions. To increase an atmosphere of transparency, the mass media and political institutions are expected to engage in symbiotic relationships that allow them to achieve national objectives that serve the interest of disparate communities. In a qualitative analysis of media's role in sustainability of the political process, The World Bank (2000) substantiates media's fundamental goal of catering to the needs of the people and increasing their confidence in government programs. Because citizens depend on the media for an understanding of issues, it would be appropriate that the mass media, as watchdogs, are involved or have access to policy formation and implementation processes in countries where leadership credibility is either questionable or nonexistent. It is noteworthy that some sustainable development policies of governments are complex or even challenging to the citizenry; therefore, it is important to allow the media to analyze program objectives.

In the wake of democratic reforms in the newly independent African nations towards sustainable political agenda, research on democracy, development, and media (Nwokeafor, 2010; Okoro, 2010; Nwanko, 2000) demonstrated that all forms of media should embark on the fundamental role of analyzing and evaluating political issues and needs in the region. Essential to this role is ensuring that political leaders are accountable and transparent in the performance of their duties. Election processes should be refined and made more rigorous in order to reduce the tendency to abuse the system by overzealous party members. Recent studies and debates on media and development clearly indicate that post-independence initiatives in some African countries point to an urgent need for effectiveness of the mass media to challenge any governance that would support or establish a political environment against ethnic and social integration. With this objective, sustainability of political development becomes a realistic goal in a developing continent. For example, more recent events in many parts of Africa (Okoro, 2010) demonstrate that effective use of the media, especially the new media, can improve the quality of governance and will foster accountability at all levels.

\section{The Media and Sustainability of Political Development}

Independent economic and financial institutions, including academic researchers, have argued favorably to reposition the mass media to play the central role of supporting democratic governance and reforms, especially in Africa, where development objectives have faced serious problems. As The World Bank (2009) explained, the $20^{\text {th }}$ century was a period of mass media development as well as an expansion of global media. An era in which news sources were involved in one-directional, top-down content coverage, and dissemination of issues to stakeholders. Interestingly, the twenty-first century is experiencing a dramatic improvement in the role of the media, especially in providing transformational and expanded structure of news dissemination across the globe with the assistance of media technology. The improvement of media's effectiveness in sustaining democracies has not only increased public confidence in the electioneering campaigns in developing nations, but it has also engendered ethnic/tribal interests and participation in political activities, which was extremely difficult in the twenty century. The difference between the role of the media in the $20^{\text {th }}$ and $21^{\text {st }}$ centuries is clearly the digitalization of content and its world-wide distribution over digital platforms through digital mechanisms and devices. A digital transformation mechanism employs new devices that supplement and effectively by-passes traditional communication platforms that utilize two-way, bottom up, and lateral content production and dissemination.

The nature of the relationship of the mass media with governments in Africa is fundamentally important in order to achieve sustainable democratic governance. Deliberate marginalization of the communication channels of news sources is disingenuous and should be considered the single most important factor that has for decades affected and discouraged the citizenry from participation in the political process. Indeed, studies conducted in the eighties and nineties (Obotette, 1981; Megwa, 1989; Okoro, 1993) determined that the hostile relationship between the two entities (media and government) has been instrumental to the unsustainable democracies in the regions of Africa. In his past and recent study (Okoro, 1993; 2010) maintained the position that to achieve and sustain political development in Nigeria (and in African countries), the concepts of "free enterprise and the "marketplace of ideas" should be nurtured by the political system in the country. He further emphasized that democratic transformation in the Nigeria should be tailored toward increasing public awareness and participation of various stakeholders in political development. 
The rate of progress in developed nations (United States, United Kingdom, etc.) has continued to evolve because of the sophistication and independence of their media systems. Citizens of these countries depend on the media for information and knowledge and to hold governments accountable for their actions. There is a growing public confidence in the ability of the mass media to expose corruptions and wrong-doings in public and private sectors, as well as the media's capacity to investigate and reveal sensitive issues associated with public policies and their implementation. The development of new media has greatly expanded the functions of the media especially in the United States. The World Electronic Media Forum (2005) noted that the new media did not emerge to replace the old channels. Instead, the new- and old media systems should work together and simultaneously to achieve the objective of news production and distribution around the world. For example, hardcopy newspapers and books are still in use and accessed on the Internet. News items are retrieved on radios, watched on television stations, and accessed on laptop computers and various mobile cellular telephones. On the contrary, in developing societies of Africa, especially in the rural parts of the countries, radio and television stations are the only means of communicating to people mainly in areas with low literacy. Increasingly, traditional radios and television channels have remained the most effective sources of disseminating or delivering news and information on critical matters affecting education, health-care, culture, and other social activities.

Sustainable political development and stability is not only a concept, but a realistic objective in Africa as long as key players in the process are involved. Since the 1950s-1960s when a number of African countries achieved national independence and others became a republic, there has been a desperate search for economic growth and political stability. For decades, various African leaders have continued to focus their efforts in translating their nationalist aspirations into objective realities. Early African scholars expressed optimism in the search for political development in the continent and suggested the inclusion of critical institutions and transparent practices. For example, Ansah (1988) pointed out that the search for political stability and development "has stretched over the whole field of political structures, economic systems, societal arrangements and institutional mechanisms for responding to the challenges of modern society" (p. 3). The author specifically identified Africa's move from "multi-party to single-party systems, or non-party military regimes; from centrally-planned, state-dominated, interventionist systems to liberal and market-oriented; and free enterprise economies with or without the prodding or control of international financial institutions.

\section{Press Freedom, Democratic Governance, and Political Development}

Studies spanning over three decades have consistently argued for freedom of the press as a pre-requisite for democratic governance. The media in developed nations are seen as watchdogs of the public interest than as merely conduits of government agenda and information. The watchdog function of the mass media is protective of stakeholders' interest and ensures that accountability and transparency exist in a democracy. It therefore stands to reason that political development and press freedom are intertwined in the effort to establish stability in a civil society. In advanced democracies, private media stimulate national reforms by exposing mismanagement and abuses at all levels of government, and reveals corrupt practices as well as questionable behaviors and standards in public sectors of the economy. Authors Graber (2010), Okigbo (2000), and The World Bank (2009) strongly indicate that better governance and effective public policy are inseparable and are the foundation of democracy. Olowu et al. (2002) emphasized that successful capacity building and democratic renewal in Africa is the function of an independent media. Therefore, the desire for a sustainable political development is realistic as long as it includes the role of strong and vibrant mass media.

In a paper written over a decade ago focused on "Press Freedom and the Imperatives of Democracy: Towards Sustainable Development," MBayo, Nwokeafor, and Onwumechili (1995) described the mass media as a fundamental element of democracy and stressed that for mass communication to function effectively and serve its meaningful role towards achieving desirable sustainable development, it must be transparent, accountable, and responsible. The paper further maintained that the drive towards sustainable democratic status is no longer debatable, because freedom of the media in countries with participatory/liberal democracies is higher than in authoritarian/dictatorial societies, where communication media is subjected to mere purveyor of political news and information. Consistent with the views of other communication scholars, the paper stressed that the quest to promote democratic institutions in African societies must include effective participation of independent mass media in defining, evaluating, and analyzing political issues, democratic processes, appropriate campaign strategies.

In recent times, discussions and debates about political, economic, and national development issues have often centered on general and specific functions of mass communication. The World Bank (2009) explained that the creation and dissemination of knowledge and innovation have been the primary components in the development process in which the media have been largely instrumental as a "means of storing and sharing knowledge." 
This specific function is performed in both developed and developing nations of the world. For example, it was noted that the United Kingdom Department for International Development (2006) identifies the effectiveness of radio in promoting development in a wide range of disparate countries, such as Afghanistan, Moldova, and Kiribati. While the mass media have been globally recognized as fostering development and change, their contributions to political development depends to a large extent on the nature of the content provided.

Essentially, in political and social environments, the well-recognized functions of the media are to inform, educate, entertain, and evaluate the activities of governments, associations, organizations, and citizens in the pursuit of democratization. In Africa as well as in other parts of the world efforts toward sustainable political development has attracted the interest of The World Bank and other global institutions. For example, The World Bank (2009) buttressed major functions of mass communication as "strengthening democracy, social development, gender equality, nation building, education provision, and the spiritual and moral fiber of society." Additionally, it includes "safeguarding, enriching, and strengthening the country's cultural, political, social, and economic fabric" (p. 2). As development initiatives expand and become more and more complex in recent years, the role and contributions of the media to political and economic developments in the developing world are re-evaluated; because in the $21^{\text {st }}$ century information age, the media are expected to play a pivotal and strategic role towards sustainability of democratic values.

\section{Media's Contributions to Nation-Building}

In modern democracies, the news media play a vital or indispensable role in the creation and shaping as well as reflecting the opinions and perspectives of people and establishments. The question that is often asked in recent times is whether there could be discussions of development without examining the strategic position of mass media. Over many years, the media have become increasingly powerful and dominant that it has taken on the status of "Fourth Estate" in developed democratic systems. The crucial function of enlightening and educating citizens, as well as raising awareness through advocating issue and transferring knowledge, skills, technologies, and innovations to people are some of the primary responsibility ascribed to the media in contemporary societies. Past and present media scholars and practitioners agree that these functions are necessary in order that democratic governance and public establishments can be established and sustained.

In African development context, communication channels are expected to play expansive and engaging role in propagating the importance of rural development initiatives, such as family planning, healthcare, and educational programs designed to improve the standard of living. In the wake of conflicting ideas, the media play an essential role of objectively analyzing unacceptable practices that impede development objectives in emerging democratic nations of Africa, where there has been strong resistance against modern processes and practices for better quality of life. Nation-building is a function of sustained democratic values driven by public knowledge. For instance, during national elections the mass media have the responsibility of guiding, shaping, and refining public perceptions and decisions for and against political candidates.

The World Bank (2009) working paper number 158 identifies media's development impact in five inter-related dimensions as follows: "Plurality and transparency, behavioral, infrastructure and platform, economic, and trade" (p. 5). In assessing media's role in political development, the contributions which a supportive media environment can make to effective governance and functioning of free markets are invaluable. In the traditional societies of Africa, the media's role in changing old values and explaining the importance of change is of inestimable value.

From the genesis of political communication to the present day, researchers and world organizations have distinctly identified the position of the media as an instrumental influence as well as a major participant on political development (Graber, 2010; The World Bank, 2009; Diamond, 2004). African intellectuals and experts across academic disciplines continue to emphasize in the literature the widespread failure of the post-independence development strategies, and suggested a refocus that will clearly integrate the role of the media toward sustainable political development efforts. If African nations expect recognition and respect in world political context, greater emphasis must be placed on the sustainability of economic and political stability.

\section{Concluding Remarks}

Indeed, sustainability of political development goal in Africa is quite realistic and achievable in the twenty-first political landscape. However, what remains is the presence of independent and vibrant mass communication systems that can perform the agenda-setting functions of the western media. The function that defines and enhances the credibility of the media in developed nations and democracies. While past relationship between news sources and governments in Africa has been characterized as hostile and criticized over time, it should be realized that public perception plays a significant role in government decisions in the formation and 
implementation of public policies. It is well-documented that mass communications in developing nations have had an uncomfortable but interdependent relationship with government agencies and various establishments, which has led to the loss of credibility in news dissemination as well as citizens' lack of confidence in government activities and programs. A sustainable political development environment in Africa is critical and can be achieved through empowering the media with tools of objectivity and integrity, a position that has been supported by mass communications scholars over decades of political independence and democratic governance in Africa.

\section{References}

Ansah, P. A. V. (1988). In search of a role for the African media in the democratic Process. Africa Media Review. Vol. 2 No. 2. African Council on Communication Education.

Awa, N. E. (1989). National development. In M. Asante and W. Gudynst (Eds.). Handbook of international and Intercultural Communication. Beverly Hills, CA: Sage Publications, Inc.

Bennett, W. L. (2003). News: The politics of illusion ( $5^{\text {th }}$ edition). New York: Longman Publishing, Inc.

Casmir, F. L. (1991). Communication in Development. Norwood, New Jersey: Ablex Publishing Group.

Boas, N. K. (2009). Social conflict, communication and youth in Tanzania. In Communication in an era of Global Conflicts: Principles and Strategies For $21^{\text {st }}$ Century Africa. Edited by Richard T. M'Bayo, Chuka Onwumechili, and Bala Musa. United Press of America: Lanham, MD.

Diamond, L. (2004). Promoting real reform in Africa. In Democratic reform in Africa: The quality of progress. Edited by E. Gymah-Boadi. Boulder, Co.: Lynne Rienner Publishers, Inc.

Entman, R. M. (1989). Democracy without citizens. Media and the decay of American Politics. New York: Oxford University Press.

Faringer, G. L. (1991). Press freedom in Africa. New York: Praeger Publishers, Inc.

Graber, D. A. (2010). Mass media and American politics ( $8^{\text {th }}$ edition). Washington, DC: Congressional Quarterly, Inc.

Guta, H. A. (2010). Media and peace-building in Sudan. In Media and Technology in Emerging African Democracies. Edited by Cosmas U. Nwokeafor And Kehbuna Langmia. United Press of America, Inc.: Lanham, MD.

Langmia, K. (2010). The role of online media technology and democratic discourse in Cameroon: A case study of the Post and Cameroon Tribute. In Media and Technology in Emerging African Democracies. Edited by Cosmas U. Nwokeafor and Kehbuna Langmia. United Press of America, Inc.: Lanham, MD.

M'Bayo, R.T. (2000). The African press: Prospects for freedom in the new Millennium. In Press and Politics in Africa. Edited by Richard Tamba M'Bayo, Chuka Onwumechili, R. Nwafor Nwanko. The Edwin Mellen Lampeter, Wales: The Edwin Mellen Press.

M'Bayo, R., Nwokeafor, C., \& Onwumechili, C. (1995). Press freedom and the imperatives of democracy: Towards sustainable development. African. Council on Communication Education.

McCombs, M., \& Reynolds, A. (2009). How the news shapes our civic agenda. Media effects advances in theory and research. Edited by Jennings and Mary Beth Oliver. Lawrence Erbaum Associates, Inc: New York: NY.

McLeod, D., Kiosicki, G.M., \& McLeod, J. M. (2009). Political communication effects. Media effects: Advances in theory and research. Edited by Jennings Bryant and Beth Oliver. Lawrence Erlbaum Associates, Inc.: New York: NY.

Megwa, E. R. (2009). Agenda-setting: African media and conflict. In communication in an era of global conflicts: Principles and strategies for the $21^{\text {st }}$ century Africa. Edited by Richard T. M'Bayo, Chuka Onwumechili, and Bala A Musa. United Press of America: Lanham, MD.

Mukasa, S. G. (2000). Press and politics in Zimbabwe. In Press and politics in Africa. Edited by Richard Tamba M’Bayo, Chuka Onwumechili, R. Nwafo Nwanko. Lampeter, Wales: The Edwin Mellen Press.

Nwanko, R. N. (1992). Press, politics, and state in Africa. Theoretical framework and overview: In Press and politics in Africa. Edited by Richard Tamba M'Bayo, Chuka Onwumechili, and R. Nwafo. Lampeter, Walels: The Edwin Mellen press. 
Nwokeafor, C. U., \& Nwanko, R. N. (1993). Development information content in the African mass media: A study of two Nigerian dallies. African Media Review, 7(3), 75-90.

Nwokeafor, C. U. (1992). Development communication in the Nigerian mass media: A study of selected publications. Unpublished doctoral dissertation, Howard University, Washington, DC.

Obotette, B.E. (1981). Mass communication for national development in Nigeria. Analysis of content and structure. Unpublished doctoral dissertation, Howard University, Washington, DC.

Okigbo, C. (1992). Horse race and issues in Nigeria elections. Journal of Black Studies, 22, 3. http://dx.doi.org/10.1177/002193479202200302

Okoro, E. A. (2009). Communication, civil society, and democratization in Africa: Perspectives on political development. In Communication in an Era of Global Conflicts: Principles and Strategies for the $21^{\text {st }}$ Century Africa. Edited by Richard T. M'Bayo, Chuka Onwumechili, and Bala A. Musa. United Press of America: Lanham, MD.

Okoro, E. A. (1993). The press and politics in Nigeria: Toward a conceptual framework for political development. Unpublished doctoral dissertation, Howard University Washington, DC.

Olowu, D., \& Sako S. (2002). Better governance and public policy: Capacity building and democratic renewal in Africa. The African Capacity Building Foundation: Kumarian Press, Inc.

Shivute, M. (1995). The media in post-independent Namibia. In P. Nwosu, C. Onwumechili, and R. M'Bayo (Ed.). Communication and the Transformation of Society: A developing region's perspectives Lanham, MD: University Press of America, Inc.

Steward, D. W., \& Pavlou, P. A. (2009). The effects of media on marketing Communications. Media Effects: Advances in Theory and Research Lawrence Erlbaum Associates, Inc. New York: NY.

The World Bank. (2009). The media and development: World Bank working paper Number 158. The World Bank: Washington, DC.

The World Bank. (2001). Economic Freedom of the World. Annual Report. Edited by James Gwartney \& Robert Lawson. Washington, DC: The World Bank

The World Bank Institute. (2000). The Media's Role in Curbing Corruption. Washington, D.C.: The World Bank.

The World Bank. (1989). Sub-Saharan Africa: From crisis to sustainable growth. A long term perspective study. Washington, D.C: The World Bank.

Uche, L. U. (1991). Communication and development in military political culture: A case study of a Nigerian public campaign for social change. In F. L. Casmir (Ed.). Communication in Development. Norwood, NJ: Ablex Publishing Corp.

Unger, S. J. (1991). The role of a free press in strengthening democracy. In Judith Lichtenberg (ED). Democracy and the Mass Media. New York: Cambridge United Press.

Ziegler, D., \& Asante, M. K. (1992). Thunder and silence: The mass media in Africa. Trenton, NJ: African World Press, Inc.

\section{(cc) BY}

This work is licensed under a Creative Commons Attribution 3.0 License. 